\title{
Faktor-Faktor yang Mempengaruhi Tingkat Pengungkapan Laporan Keuangan Pemerintah Daerah pada Kabupaten/Kota Provinsi Sumatera Barat Tahun Anggaran 2014-2016
}

\author{
Meri Andriani $^{1}$, Elfitri Santi ${ }^{2}$, dan Rasyidah Mustika ${ }^{3}$ \\ ${ }^{1}$ Program Studi Diploma IV Akuntansi Jurusan Akuntansi, Politeknik Negeri Padang \\ Email: meriandriani95@gmail.com \\ 2 Program Studi Diploma IV Akuntansi Jurusan Akuntasi, Politeknik Negeri Padang \\ Email: elfitrisanti@ymail.com \\ ${ }_{3}^{3}$ Program Studi Diploma IV Akuntansi Jurusan Akuntasi, Politeknik Negeri Padang \\ Email: titik.mustika@gmail.com
}

\begin{abstract}
This study aims to examine and analyze the influence of local government size, dependency level, age of local government, legislative size, population, regional income, functional differentiation and capital expenditure on the level of disclosure of local government financial reports to district/city regional governments in West Sumatra Province. The population of this study is the district/city regional government in West Sumatra Province with the sample used is the regional government financial report on the District/City Regional Government in West Sumatra Province for the period 2014-2016. The sample included in the criteria of this study were 57 local government financial reports using purposive sampling method. Data analysis method in this research uses multiple linear regression analysis with SPSS 20 program. The results of the research show that the legislative size and the number of population affect the level of disclosure of local government financial statements, but the size of the local government, the level of dependence, the age of local governments, regional income, functional differentiation and capital expenditure do not affect the level of disclosure of local government financial statements.
\end{abstract}

Keywords: Local Government Financial Statement, Disclosure, Government Accounting Standard

\begin{abstract}
ABSTRAK
Penelitian ini bertujuan untuk menguji dan menganalisis pengaruh ukuran pemerintah daerah, tingkat ketergantungan, umur pemerintah daerah, ukuran legislatif, jumlah penduduk, pendapatan asli daerah, diferensiasi fungsional dan belanja modal terhadap tingkat pengungkapan laporan keuangan pemerintah daerah pada pemerintah daerah kabupaten/kota di Provinsi Sumatera Barat. Populasi penelitian ini adalah pemerintah daerah kabupaten/kota di Provinsi Sumatera Barat dengan sampel yang digunakan adalah laporan keuangan pemerintah daerah pada Pemerintah Daerah Kabupaten/Kota di Provinsi Sumatera Barat periode tahun 2014-2016. Sampel yang masuk dalam kriteria penelitian ini sebanyak 57 laporan keuangan pemerintah daerah dengan menggunakan metode purposive sampling. Metode analisis data dalam penelitian ini menggunakan analisis regresi linier berganda dengan program SPSS 20. Hasil penelitian menunjukkan bahwa ukuran legislatif dan jumlah penduduk berpengaruh terhadap tingkat pengungkapan LKPD, tetapi ukuran pemerintah daerah, tingkat ketergantungan, umur pemerintah daerah, pendapatan asli daerah, diferensiasi fungsional dan belanja modal tidak berpengaruh terhadap tingkat pengungkapan LKPD.
\end{abstract}

Kata Kunci: Laporan Keuangan Pemerintah Daerah, Pengungkapan, Standar Akuntansi Pemerintahan 


\section{PENDAHULUAN}

Dalam kurun waktu 12 tahun di era reformasi, Indonesia sedang melakukan pembenahan di segala bidang. Termasuk pembenahan dalam pengelolaan keuangan negara. Saat ini pemerintah dituntut untuk lebih transparan memberikan informasi terkait pengelolaan keuangan negara kepada masyarakat. Terlebih adanya UndangUndang No 14 Tahun 2008 tentang Keterbukaan Informasi Publik, dimana pada undang-undang ini badan publik memiliki kewajiban untuk menyediakan, memberikan dan/atau menerbitkan informasi publik yang berada dibawah kewenangannya. Laporan keuangan yang diterbitkan oleh lembaga publik merupakan barang publik yang berhak diperoleh oleh masyarakat.

Untuk mewujudkan transparansi anggaran, pemerintah telah mengeluarkan Peraturan Pemerintah Nomor 71 Tahun 2010 tentang standar akuntansi pemerintahan untuk mengganti Peraturan Pemerintah Nomor 24 Tahun 2005 tentang standar akuntansi pemerintahan. Ada perbedaan mendasar atas kedua peraturan tersebut yaitu pada transaksi yang dilakukan. Pada Peraturan Pemerintah Nomor 24 Tahun 2005 pencatatan transaksi berbasis kas, sedangkan pada Peraturan Pemerintah Nomor 71 Tahun 2010 pencatatan transaksi berbasis akrual. Pada Peraturan Pemerintah Nomor 71 Tahun 2010 terdapat 2 lampiran yaitu lampiran I merupakan standar akuntansi pemerintah berbasis akrual yang akan dilaksanakan 4 tahun setelah peraturan diterbitkan. Pada lampiran II merupakan standar akuntansi berbasis kas menuju akrual yang berlaku sampai tahun 2014, yang berlaku bagi pemerintah daerah yang belum siap menerapkan standar akuntansi pemerintahan berbasis akrual.

Untuk melaksanakan undang-undang tersebut Kementerian Dalam Negeri mengeluarkan Peraturan Dalam Negeri Nomor 64 Tahun 2013 tentang penerapan standar akuntansi pemerintahan berbasis akrual pada pemerintah daearah. Dalam Peraturan Menteri Dalam negeri Nomor 64 Tahun 2013 Pasal 1 point 15 menyebutkan bahwa pengungkapan adalah laporan keuangan yang menyajikan secara lengkap informasi yang dibutuhkan oleh pengguna. Selanjutnya untuk point 16 sampai dengan 22 menyebutkan komponen laporan keuangan pemerintah pusat/daerah antara lain Laporan Realisasi Anggaran (LRA), Laporan Perubahan Saldo Anggaran Lebih (LPSAL), Neraca, Laporan Operasional (LO), Laporan Arus Kas (LAK), Laporan Perubahan Ekuitas (LPE) dan Catatan atas Laporan Keuangan (CaLK).

Menurut Pernyataan Standar Akuntansi Pemerintahan (PSAP) Nomor 1 Paragraf 24 menyatakan bahwa entitas pelaporan mengungkapan informasi tentang ketaatan terhadap anggaran. Begitu pula dalam paragraf-paragraf selanjutnya yang menjelaskan pentingya pengungkapan semua informasi keuangan yang dibutuhkan pengguna sebab hal ini untuk menghindari kekeliruan dan kesalahpahaman dalam membaca laporan keuangan. Pemenuhan akan adanya pengungkapan akan mempermudah pengguna laporan keuangan dalam memahami isi dari laporan keuangan tersebut. Pengungkapan laporan keuangan yang bersifat wajib sesuai dengan Pernyataan Standar Akuntansi Pemerintahan (PSAP) yang akan dijadikan dasar dalam penelitian ini.

Berdasarkan hasil audit Badan Pemeriksa Keuangan (BPK) Republik Indonesia, Pemerintah Provinsi Sumatera Barat kembali mendapatkan opini Wajar Tanpa Pengecualian (WTP). Opini tersebut diperoleh atas Laporan Keuangan Pemerintah Daerah tahun 2016. Opini WTP ini merupakan kelima kalinya secara berturut-turut bagi Sumatera Barat. Meski mendapatkan opini WTP, BPK masih menemukan 
sejumlah permasalahan. BPK menemukan 30 item dalam Laporan Keuangan Pemerintah Daerah Provinsi Sumatera Barat tahun 2016. Menurut anggota V BPK RI Isma Yatun mengungkapan BPK masih menemukan beberapa permasalahan yang perlu mendapat perhatian. Antara lain temuan pemeriksaan atas Sistem Pengendalian Internal (SPI) dan kepatuhan terhadap peraturan perundangundangan. Isma Yatun menyebutkan, temuan SPI antara lain pengendalian atas pertanggungjawaban belanja Bahan Bakar Minyak (BBM) pada tujuh Organisasi Pemerintah Daerah (OPD) tidak diyakini keterjadiaanya, nilainya mencapai Rp1,24 miliar. Kemudian pelaksanaan dan pertanggungjawaban belanja pada Sekretariat DPRD Provinsi Sumatera Barat tidak dapat diyakini kewajarannya dengan nilai sekitar Rp 4,24 miliar.

Pertanggungjawaban belanja Alat Tulis Kantor (ATK) dan bahan habis pakai pada 11 OPD juga tidak didukung dengan bukti lengkap. BPK menyebutkan nilainya Rp5,4 miliar. Sementara itu, temuan pemeriksaan menyangkut kepatuhan terhadap peraturan perundang-undangan diantaranya kelebihan pembayaran atas pengadaan barang dan jasa sekitar Rp123,2 juta, serta terdapat barang inventaris yang dikuasai oleh yang tidak berhak. Wakil ketua DPRD Provinsi Sumatera Barat Arkadius Datuak Intan Bano yang memimpin rapat paripurna istimewa menegaskan, keberhasilan tata kelola keuangan tidak semata-mata ditunjukkan dari opini WTP. Keberhasilan juga dilihat dari sejauh mana pemerintah daerah telah menindaklanjuti semua rekomendasi terhadap laporan keuangan pemerintah daerah tersebut, termasuk rekomendasi perbaikan yang diberikan oleh DPRD (www.sumateratime.com/2017/05).

Faktor-faktor yang mempengaruhi tingkat pengungkapan Laporan Keuangan Pemerintah Daerah (LKPD) masih menjadi perdebatan. Penelitian serupa pernah dilakukan oleh Naopal, dkk (2017), Madelia, dkk (2017), Setyowati (2016), Fadilah dan Nucholisah (2016), Maulana dan Handayani (2015), Hendriyani dan Tahar (2015), Yusup (2014), Khasanah dan Rahardjo (2014), Setyaningrum dan Syafitri (2012), Suhardjanto dan Yulianingtyas (2011). Namun dari hasil penelitian terdahulu masih terdapat perbedaan-perbedaan. Berdasarkan penelitian terdahulu ada beberapa variabel yang memiliki hasil yang berbeda yaitu ukuran pemerintah daerah, tingkat ketergantungan, umur pemerintah daerah, ukuran legislatif, jumlah penduduk, pendapatan asli daerah, jumlah OPD dan belanja modal. Penelitian terdahulu banyak menggunakan populasi dan sampel pada pemerintahan di Pulau Jawa dan pada pemerintahan di seluruh provinsi yang ada di Indonesia.

Berdasarkan hasil penelitian yang tidak konsisten dengan variabel-variabel tersebut diatas maka peneliti tertarik untuk menganalisis lebih dalam tentang faktorfaktor yang mempengaruhi tingkat pengungkapan laporan keuangan pemerintah daerah pada kabupaten/kota Provinsi Sumatera Barat dengan menggunakan data mulai tahun 2014 sampai dengan 2016.

Berdasarkan latar belakang tersebut dapat dirumuskan rumusan masalah dalam penelitian ini yaitu; (1) Apakah ukuran pemerintah daerah berpengaruh terhadap tingkat pengungkapan Laporan Keuangan Pemerintah Daerah (LKPD)? (2) Apakah tingkat ketergantungan berpengaruh terhadap tingkat pengungkapan Laporan Keuangan Pemerintah Daerah (LKPD)? (3) Apakah umur pemerintah daerah berpengaruh terhadap tingkat pengungkapan Laporan Keuangan Pemerintah Daerah (LKPD)? (4) Apakah ukuran legislatif berpengaruh terhadap tingkat pengungkapan Laporan Keuangan Pemerintah Daerah (LKPD)? (5) Apakah jumlah penduduk 
berpengaruh terhadap tingkat pengungkapan Laporan Keuangan Pemerintah Daerah (LKPD)? (6) Apakah pendapatan asli daerah berpengaruh terhadap tingkat pengungkapan Laporan Keuangan Pemerintah Daerah (LKPD)? (7) Apakah diferensiasi fungsional berpengaruh terhadap tingkat pengungkapan Laporan Keuangan Pemerintah Daerah (LKPD)? (8) Apakah belanja modal berpengaruh terhadap tingkat pengungkapan Laporan Keuangan Pemerintah Daerah (LKPD)? Sedangkan tujuan penelitian ini adalah; (1) Menganalisis pengaruh ukuran pemerintah daerah terhadap tingkat pengungkapan Laporan Keuangan Pemerintah Daerah (LKPD) pada Provinsi Sumatera Barat. (2) Menganalisis pengaruh tingkat ketergantungan terhadap tingkat pengungkapan Laporan Keuangan Pemerintah Daerah (LKPD) pada Provinsi Sumatera Barat. (3) Menganalisis pengaruh umur pemerintah daerah terhadap tingkat pengungkapan Laporan Keuangan Pemerintah Daerah (LKPD) pada Provinsi Sumatera Barat. (4) Menganalisis pengaruh ukuran legislatif terhadap tingkat pengungkapan Laporan Keuangan Pemerintah Daerah (LKPD) pada Provinsi Sumatera Barat. (5) Menganalisis pengaruh jumlah penduduk terhadap tingkat pengungkapan Laporan Keuangan Pemerintah Daerah (LKPD) pada Provinsi Sumatera Barat. (6) Menganalisis pengaruh pendapatan asli daerah terhadap tingkat pengungkapan Laporan Keuangan Pemerintah Daerah (LKPD) pada Provinsi Sumatera Barat. (7) Menganalisis pengaruh diferensiasi fungsional terhadap tingkat pengungkapan Laporan Keuangan Pemerintah Daerah (LKPD) pada Provinsi Sumatera Barat. (8) Menganalisis pengaruh belanja modal terhadap tingkat pengungkapan Laporan Keuangan Pemerintah Daerah (LKPD) pada Provinsi Sumatera Barat.

\section{METODE PENELITIAN Jenis Penelitian}

Penelitian ini merupakan penelitian deskriptif kuantitatif yaitu penelitian yang berusaha menjelaskan variabel-variabel dengan pengumpulan data yang akan diolah untuk melihat pengaruh dari variabel tersebut. Penelitian ini juga merupakan penelitian eksplanatory, untuk memperoleh kejelasan fenomena yang terjadi di dunia empiris (real world) dan berusaha untuk mendapatkan jawaban (verificative), yang bertujuan untuk menjelaskan hubungan kausalitas antara variabel-variabel melalui analisis data dalam rangka pengujian hipotesis (Satria, 2015).

\section{Populasi dan Sampel}

Penelitian ini menggunakan populasi berupa pemerintah daerah kabupaten/kota di Provinsi Sumatera Barat. Jumlah pemerintah daerah kabupaten/kota yang ada di Provinsi Sumatera Barat adalah sebanyak 19 pemerintah daerah yang terdiri 7 (tujuh) pemerintah kota dan 12 pemerintah kabupaten. Sedangkan sampel yang digunakan adalah laporan keuangan pemerintah daerah pada pemerintah daerah kabupaten/kota di Provinsi Sumatera Barat periode tahun 2014-2016. Teknik pengambilan sampel yang digunakan dalam penelitian ini adalah melalui pendekatan non probability sampling yaitu purposive sampling. Berdasarkan purposive sampling, maka pemilihan sampel dilakukan sesuai tujuan penelitian atau pertimbangan tertentu.

Pemilihan sampel yang dilakukan dengan cara purposive sampling maka penentuan sampelnya dilakukan berdasarkan kriteria-kriteria yang dibuat oleh peneliti (Sekaran, 2010). Adapun pertimbangan atau kriteria yang digunakan dalam 
pemilihan sampel penelitian ini adalah: (1) Laporan Keuangan Pemerintah Daerah (LKPD) Kabupaten/Kota di Provinsi Sumatera Barat periode 2014-2016 yang telah diaudit oleh BPK. (2) Laporan Keuangan Pemerintah Daerah yang telah mendapatkan opini WTP (Wajar Tanpa Pengecualian) dan WDP (Wajar Dengan Pengecualian) pada periode tahun 2014-2016.

\section{Teknik Pengumpulan Data}

Teknik pengumpulan data yang digunakan dalam penelitian ini adalah metode studi dokumentasi, dengan memperoleh data berupa laporan tahunan. Laporan tahunan yang diperoleh adalah laporan keuangan pemerintah daerah kabupaten/kota pada Provinsi Sumatera Barat yang dikeluarkan oleh BPK RI perwakilan Sumatera Barat. Pengumpulan data dilakukan dengan melihat data-data yang diperlukan, mencatat dan menganalisis laporan keuangan pemerintah daerah tahunan pada periode tahun 2014- 2016.

\section{Teknik dan Metode Analisis Data}

Dalam penelitian ini, pengujian dilakukan dengan analisis regresi linear berganda. Persamaan regresi linier berganda dalam penelitian ini adalah:

$$
\mathrm{Y}=\alpha 0+\beta 1 \mathrm{X} 1+\beta 2 \mathrm{X} 2+\beta 3 \mathrm{X} 3+\beta 4 \mathrm{X} 4+\beta 5 \mathrm{X} 5+\beta 6 \mathrm{X} 6+\beta 7 \mathrm{X} 7+\beta 8 \mathrm{X} 8+\varepsilon
$$

Keterangan:

$\begin{array}{ll}\mathrm{Y} & \text { : Tingkat Pengungkapan LKPD } \\ \alpha 0 & : \text { Konstanta } \\ \mathrm{X} 1 & : \text { Ukuran Pemerintah Daerah } \\ \mathrm{X} 2 & \text { : Tingkat Ketergantungan } \\ \mathrm{X} 3 & : \text { Umur Pemerintah Daerah } \\ \mathrm{X} 4 & : \text { Ukuran Legislatif } \\ \mathrm{X} 5 & \text { : Jumlah Penduduk } \\ \mathrm{X} 6 & : \text { Pendapatan Asli Daerah } \\ \mathrm{X} 7 & : \text { Diferensiasi Fungsional } \\ \mathrm{X} 8 & : \text { Belanja Modal } \\ \beta 1 \ldots \beta 8 & : \text { Koefisien X1...X3 } \\ \varepsilon & : \text { Error }\end{array}$

\section{HASIL DAN PEMBAHASAN}

Data penelitian diolah menggunakan analisis regresi linier berganda dengan aplilkasi SPSS versi 20.

\section{Analisis Statistik Deskriptif}

Statistik deskriptif memberikan gambaran atau deskripsi suatu data yang dilihat dari nilai rata-rata (mean), standar deviasi, varian, maksimum, minimum, sum, range, 
kurtosis dan skewness/kemencengan distribusi (Ghozali, 2016:19). Deskripsi keseluruhan variabel penelitian ini terlihat pada Tabel 1 berikut:

Tabel 1. Hasil Uji Statistik Deskriptif

Descriptive Statistics

\begin{tabular}{|c|c|c|c|c|c|}
\hline & $\mathrm{N}$ & Minimum & Maximum & Mean & Std. Deviation \\
\hline Uluuran Domd & 57 & 64597456570 & 78850407002 & 1797758641682,0 & 13636188009 \\
\hline Ukuran Pemda & $5 /$ & & 85 & & 87,787 \\
\hline Tingkat Ketergantungan & 57 & 60,03 & 91,08 & 78,1035 & 6,23062 \\
\hline Umur Pemda & 57 & 10 & 347 & 85,16 & 90,010 \\
\hline Ukuran Legislatif & 57 & 20 & 45 & 30,79 & 9,151 \\
\hline Jumlah Penduduk & 57 & 50208 & 914968 & 273468,40 & 206767,643 \\
\hline PAD & 57 & 26677826164 & 39192566264 & 8093454400325 & 70316723136, \\
\hline & & & 7 & & 261 \\
\hline Diferensiasi Fungsional & 57 & 27 & 54 & 37,63 & 6,546 \\
\hline Belanja Modal & 57 & 64712665446 & 40831007628 & 185284068138,91 & 68380376702 , \\
\hline & & & 7 & & 309 \\
\hline Tingkat Pengungkapan & 57 & 22,73 & 86,36 & 63,2389 & 9,30142 \\
\hline Valid N (listwise) & 57 & & & & \\
\hline
\end{tabular}

Sumber: Output IBM SPSS

Adapun deskripsinya dapat dijelaskan sebagai berikut:

\section{a. Variabel dependen}

Variabel dependen dalam penelitian ini adalah tingkat pengungkapan Laporan Keuangan Pemerintah Daerah (LKPD) berdasarkan Standar Akuntansi Pemerintahan (SAP). Tabel 1 yang merupakan hasil statistik deskriptif menunjukkan bahwa pengungkapan LKPD pada pemerintah kabupaten/kota di Provinsi Sumatera Barat periode tahun 2014 sampai dengan 2016 terendah pada Kabupaten Kepulauan Mentawai sebesar 22,73\% sedangkan Kota Bukittinggi menunjukkan tingkat pengungkapan tertinggi sebesar $86,36 \%$.

Nilai rata-rata pengungkapan LKPD pada periode tahun 2014 sampai dengan 2016 sebesar 63,24\%, pengungkapan LKPD yang dilakukan oleh pemerintah daerah cenderung meningkat dari tahun ke tahun tetapi ada beberapa pemerintah daerah kabupaten/kota tahun 2015 dan 2016 sedikit mengalami penurunan karena pemerintah daerah harus menerapkan SAP berbasis akrual sehingga beberapa daerah cenderung belum siap dalam penerapannya.

\section{b. Variabel Independen}

Tabel 1 di atas dapat diketahui bahwa ukuran pemerintah daerah mempunyai nilai minimum sebesar Rp645.974.565.709 nilai maksimum sebesar Rp7.885.040.700.285 dengan nilai rata-rata Rp1.797.758.641.682 dan standar deviasi sebesar Rp1.363.618.800.988. Nilai minimal sebesar Rp645.974.565.709 artinya pemerintah daerah tersebut mempunyai jumlah total aset terendah yaitu pada Pemerintah 
Daerah Kota Sawahlunto sedangkan nilai maksimal sebesar Rp7.885.040.700.285 pemerintah daerah yang mempunyai jumlah total aset terbesar yaitu Pemerintah Kota Padang.

Pada tingkat ketergantungan daerah memiliki rata-rata sebesar 78,10\%, nilai tingkat ketergantungan tertinggi pada Pemerintah Daerah Kabupaten Kepulauan Mentawai sebesar 91,08\% sedangkan Pemerintah Daerah Kota Padang memiliki tingkat ketergantungan terendah dengan persentase sebesar 60,03\%.

Variabel umur pemerintah daerah di Provinsi Sumatera Barat memiliki rata-rata 85 tahun. Pemerintah daerah yang memiliki umur termuda adalah Kabupaten Dharmasraya dengan usia 10 tahun sedangkan Kota Padang memiliki umur paling tua yaitu 347.

Ukuran legislatif memiliki ukuran rata-rata sebesar 31 orang dengan ukuran legislatif tertinggi terdapat pada 3 pemerintah daerah kabupaten/kota yaitu Kabupaten Agam, Kabupaten Pesisir Selatan dan Kota Padang dengan jumlah 45 orang sedangkan ukuran legislatif terkecil terdapat pada 5 pemerintah daerah kabupaten/kota yaitu Kabupaten Kepulauan Mentawai, Kota Solok, Kota Sawahlunto, Kota Pariaman dan Kota Padang Panjang dengan jumlah 20 orang.

Jumlah penduduk memiliki jumlah rata-rata sebesar 273.468 orang dengan jumlah penduduk tertinggi terdapat pada Pemerintah Daerah Kota Padang dengan jumlah penduduk sebesar 914.968 orang sedangkan Kota padang Panjang memiliki jumlah penduduk terkecil dengan jumlah 50.208 orang.

Variabel pendapatan asli daerah kabupatan/kota Provinsi Sumatera Barat memiliki rata-rata Rp80.934.544.003. Pemerintah daerah yang memiliki pendapatan asli daerah tertinggi adalah Kota Padang sebesar Rp391.925.662.647 dan Kota Pariaman memiliki pendapatan asli daerah terendah sebesar Rp 26.677.826.164.

Diferensiasi fungsional kabupaten/kota di Provinsi Sumatera Barat memiliki rata-rata 38 OPD. Pemerintah daerah yang memiliki diferensiasi fungsional tertinggi adalah Kota Padang sebesar 54 OPD sedangkan Kota Payakumbuh dan Kota Padang Panjang memiliki diferensiasi fungsional terendah sebesar 27 OPD.

Pada belanja modal memiliki rata-rata sebesar Rp185.284.068.139 dengan belanja modal tertinggi terdapat pada Pemerintah Daerah Kota Padang sebesar Rp 408.310.076.287 sedangkan Kota Padang Panjang memiliki belanja modal terkecil sebesar Rp64.712.665.446.

\section{Koefisien Determinasi $\left(\mathbf{R}^{2}\right)$}

Koefisien Determinasi $\left(\mathrm{R}^{2}\right)$ pada intinya mengukur seberapa jauh kemampuan model dalam menerangkan variasi variabel dependen, nilai koefisien determinasi adalah antara nol dan satu (Ghozali, 2016:95). Hasil uji koefisien determinasi $\left(R^{2}\right)$ dapat dilihat pada tabel 2

Tabel 2. Hasil Uji Koefisien Determinasi $\left(\mathbf{R}^{2}\right)$

Model Summary

\begin{tabular}{|l|r|r|r|r|}
\hline Model & \multicolumn{1}{|c|}{ R } & \multicolumn{1}{|c|}{ R Square } & Adjusted R Square & \multicolumn{1}{|c|}{$\begin{array}{c}\text { Std. Error of the } \\
\text { Estimate }\end{array}$} \\
\hline 1 &, $660^{\mathrm{a}}$ &, 436 &, 342 & 7,54477 \\
\hline
\end{tabular}


a. Predictors: (Constant), Belanja Modal, Tingkat Ketergantungan, Umur Pemda,

Diferensiasi Fungsional, Ukuran Legislatif, Ukuran Pemda, PAD, Jumlah Penduduk

Sumber: Output IBM SPSS

Hasil uji koefisien determinasi $\left(\mathrm{R}^{2}\right)$ pada tabel 2 menunjukkan bahwa nilai R Square sebesar 0,436 atau 43,6\%. Nilai ini menunjukkan bahwa variabel tingkat pengungkapan laporan keuangan pemerintah daerah dapat dijelaskan sebesar 43,6\% oleh variabel ukuran pemerintah daerah, tingkat ketergantungan, umur pemerintah daerah, ukuran legislatif, jumlah penduduk, pendapatan asli daerah, diferensiasi fungsional dan belanja modal. Sedangkan sisanya sebesar 56,4\% dijelaskan oleh faktor-faktor lain yang tidak disertakan dalam model penelitian ini.

\section{Uji Model}

\section{a. Uji Signifikansi Simultan (Uji Statistik f)}

Uji signifikansi simultan (Uji statistik F) adalah pengujian yang digunakan untuk melihat pengaruh dari delapan variabel independen (bebas) terhadap variabel dependen (terikat). Berikut adalah hasil pengujian uji signifikansi simultan:

Tabel 3. Hasil Uji Statistik f

ANOVAa

\begin{tabular}{|rl|r|r|r|r|r|}
\hline \multicolumn{2}{|l|}{ Model } & \multicolumn{1}{c|}{$\begin{array}{c}\text { Sum of } \\
\text { Squares }\end{array}$} & Df & Mean Square & \multicolumn{1}{|l|}{ F } & \multicolumn{1}{c|}{ Sig. } \\
\hline \multirow{2}{*}{1} & Regression & 2112,585 & 8 & 264,073 & 4,639 &, $000^{\mathrm{b}}$ \\
& Residual & 2732,330 & 48 & 56,924 & & \\
& Total & 4844,915 & 56 & & & \\
\hline
\end{tabular}

a. Dependent Variable: Tingkat Pengungkapan

b. Predictors: (Constant), Belanja Modal, Tingkat Ketergantungan, Umur Pemda,

Diferensiasi Fungsional, Ukuran Legislatif, Ukuran Pemda, PAD, Jumlah Penduduk

Sumber: Output IBM SPSS

Hasil uji f dapat dilihat pada tabel 3 menunjukkan bahwa hasil regresi moderasi diperoleh nilai signifikan sebesar 0,000 lebih kecil dari tingkat $\alpha=0,05$. Nilai probabilitas pengujian yang lebih kecil dari $\alpha=0,05$ menunjukkan bahwa secara bersama-sama atau simultan variabel independen (ukuran pemerintah daerah, tingkat ketergantungan, umur pemerintah daerah, ukuran legislatif, jumlah penduduk, pendapatan asli daerah, diferensiasi fungsional dan belanja modal) berpengaruh terhadap variabel dependen (tingkat pengungkapan laporan keuangan pemerintah daerah). Hal tersebut mengindikasikan bahwa model regresi yang digunakan dalam penelitian ini adalah layak.

\section{b. Hasil Uji Regresi Parsial (Uji t)}

Uji statistik $\mathrm{t}$ digunakan untuk mengetahui ada atau tidaknya pengaruh masingmasing variabel independen secara individual terhadap variabel dependen yang diuji pada tingkat signifikasi 0.025 . Jika nilai probabilitas t lebih kecil dari 0.025 , maka H1 diterima dan H0 ditolak, sedangkan jika nilai probabilitas t lebih besar dari 0.025 , 
maka $\mathrm{H} 0$ diterima dan $\mathrm{H} 1$ ditolak. Berikut adalah hasil perhitungan nilai t hitung dan taraf signifikansinya dalam penelitian ini:

Tabel 4. Hasil Uji Statistik t

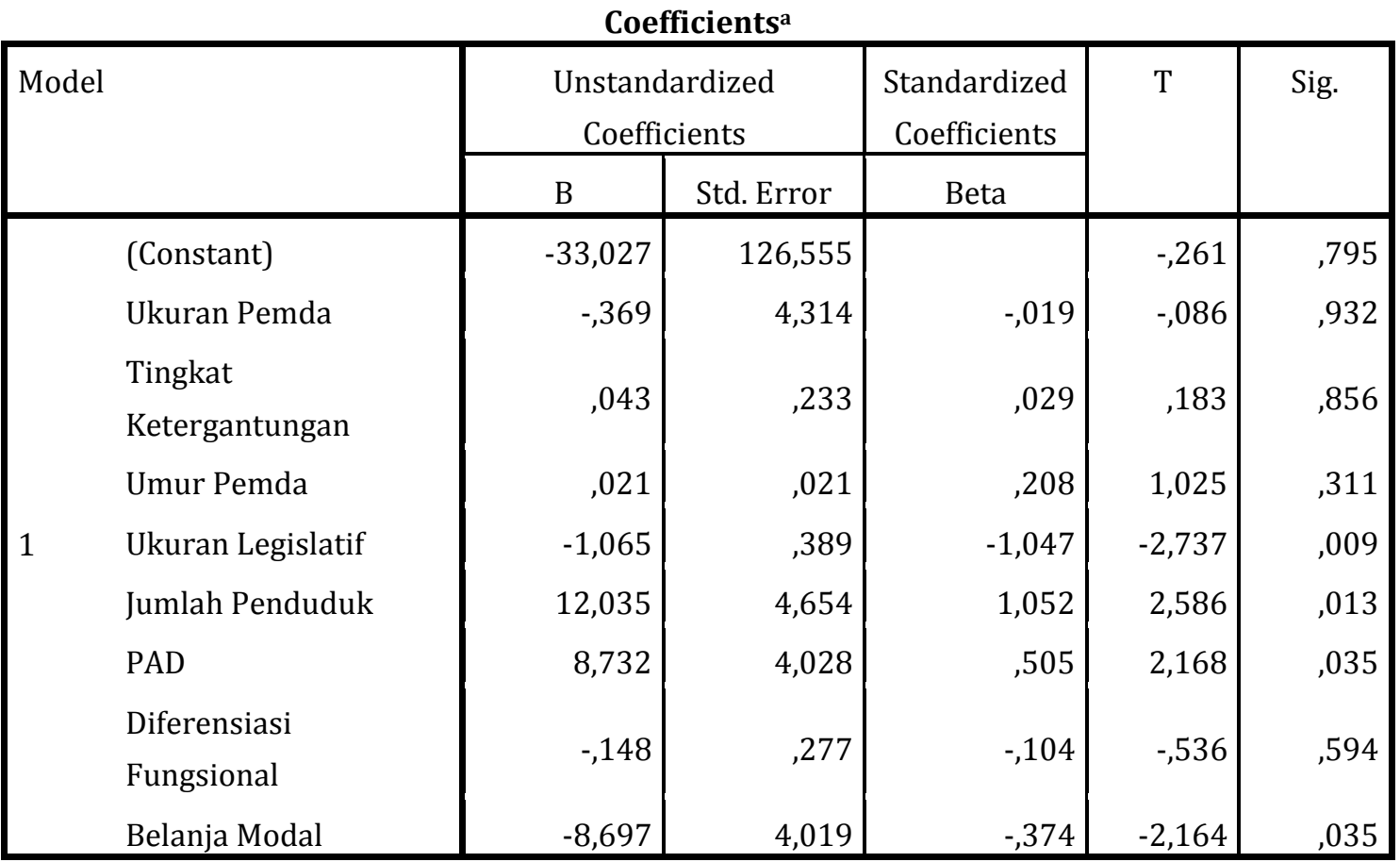

a. Dependent Variable: Tingkat Pengungkapan

Sumber: Output IBM SPSS

Variabel ukuran pemerintah daerah memiliki hasil uji yang negatif sebesar -0,369 dengan tingkat signifikansi sebesar 0,932. Tingkat signifikansi tersebut lebih besar dari 0,025 yang berarti $\mathrm{H}_{1}$ ditolak sehingga dapat dikatakan bahwa secara parsial ukuran pemerintah daerah tidak berpengaruh terhadap tingkat pengungkapan laporan keuangan pemerintah daerah.

Variabel tingkat ketergantungan memiliki hasil uji yang yang positif sebesar 0,043 dengan tingkat signifikansi sebesar 0,856. Tingkat signifikansi tersebut lebih besar dari 0,025 yang berarti $\mathrm{H}_{2}$ ditolak sehingga dapat dikatakan bahwa secara parsial tingkat ketergantungan tidak berpengaruh terhadap tingkat pengungkapan laporan keuangan pemerintah daerah.

Variabel umur pemerintah daerah memiliki hasil uji yang yang positif sebesar 0,021 dengan tingkat signifikansi sebesar 0,311. Tingkat signifikansi tersebut lebih besar dari 0,025 yang berarti $\mathrm{H}_{3}$ ditolak sehingga dapat dikatakan bahwa secara parsial umur pemerintah daerah tidak berpengaruh terhadap tingkat pengungkapan laporan keuangan pemerintah daerah.

Variabel ukuran legislatif memiliki hasil uji yang negatif sebesar -1,065 dengan tingkat signifikansi sebesar 0,009. Tingkat signifikansi tersebut lebih kecil dari 0,025 yang berarti $\mathrm{H}_{4}$ diterima sehingga dapat dikatakan secara parsial ukuran legislatif berpengaruh terhadap tingkat pengungkapan pengungkapan laporan keuangan pemerintah daerah. 
Variabel jumlah penduduk memiliki hasil uji yang yang positif sebesar 12,035 dengan tingkat signifikansi sebesar 0,013. Tingkat signifikansi tersebut lebih kecil dari 0,025 yang berarti $\mathrm{H}_{5}$ diterima sehingga dapat dikatakan secara parsial jumlah penduduk berpengaruh terhadap tingkat pengungkapan pengungkapan laporan keuangan pemerintah daerah.

Variabel pendapatan asli daerah memiliki hasil uji yang yang positif sebesar 8,732 dengan tingkat signifikansi sebesar 0,035. Tingkat signifikansi tersebut lebih besar dari 0,025 yang berarti $\mathrm{H}_{6}$ ditolak sehingga dapat dikatakan secara parsial pendapatan asli daerah tidak berpengaruh terhadap tingkat pengungkapan pengungkapan laporan keuangan pemerintah daerah.

Variabel diferensiasi fungsional memiliki hasil uji yang negatif sebesar -0,148 dengan tingkat signifikansi sebesar 0,594. Tingkat signifikansi tersebut lebih besar dari 0,025 yang berarti $\mathrm{H}_{7}$ ditolak sehingga dapat dikatakan bahwa secara parsial diferensiasi fungsional tidak berpengaruh terhadap tingkat pengungkapan laporan keuangan pemerintah daerah.

Variabel belanja modal memiliki hasil uji yang negatif sebesar -8,697 dengan tingkat signifikansi sebesar 0,035. Tingkat signifikansi tersebut lebih besar dari 0,025 yang berarti $\mathrm{H}_{8}$ ditolak sehingga dapat dikatakan secara parsial belanja modal tidak berpengaruh terhadap tingkat pengungkapan pengungkapan laporan keuangan pemerintah daerah.

Berdasarkan tabel 4 diatas menghasilkan model regresi sebagai berikut:

Tingkat pengungkapan $=-33,027-0,369 \mathrm{X} 1+0,043 \mathrm{X} 2+0,021 \mathrm{X} 3-1,065 \mathrm{X} 4+$ 12,035 X5 + 8,732 X6 - 0,148 X7 - 8,697 X8 + $\varepsilon$

Keterangan:

X1 = Ukuran Pemerintah Daerah

$\mathrm{X} 2$ = Tingkat Ketergantungan

X3 = Umur Pemerintah Daerah

$\mathrm{X} 4$ = Ukuran Legislatif

X5 = Jumlah Penduduk

X6 = Pendapatan Asli Daerah

X7 = Diferensiasi Fungsional

$\mathrm{X} 8=$ Belanja Modal

$\varepsilon=$ error

Persamaan regresi linier berganda tersebut memiliki nilai negatif pada konstanta yaitu -33,027, yang menyatakan bahwa apabila ukuran pemerintah daerah, tingkat ketergantungan, umur pemerintah daerah, ukuran legisatif, jumlah penduduk, pendapatan asli daerah, diferensiasi fungsional dan belanja modal bernilai nol maka tingkat pengungkapan LKPD akan bernilai negatif.

Koefisien regresi pada variabel ukuran pemerintah daerah bernilai $-0,369$. Tanda negatif pada koefisien regresi menunjukkan hubungan berlawanan arah antara variabel independen dengan variabel dependennya. Hal ini berarti kenaikan ukuran pemerintah daerah sebesar $1 \%$ akan menurunkan nilai tingkat pengungkapan LKPD sebesar 0,369. Koefisien regresi pada variabel tingkat ketergantungan bernilai 0,043. Tanda positif pada koefisien regresi menunjukkan hubungan searah antara variabel independen dengan variabel dependennya. Hal ini berarti kenaikan tingkat ketergantungan sebesar $1 \%$ akan menaikkan nilai tingkat pengungkapan LKPD sebesar 0,043 . 
Koefisien regresi pada variabel umur pemerintah daerah bernilai 0,021. Tanda positif pada koefisien regresi menunjukkan hubungan searah antara variabel independen dengan variabel dependennya. Hal ini berarti kenaikan umur pemerintah daerah sebesar 1\% akan menaikkan nilai tingkat pengungkapan LKPD sebesar 0,021. Koefisien regresi pada variabel ukuran legislatif bernilai -1,065. Tanda negatif pada koefisien regresi menunjukkan hubungan berlawanan arah antara variabel independen dengan variabel dependennya. Hal ini berarti kenaikan ukuran legislatif sebesar 1\% akan menurunkan nilai tingkat pengungkapan LKPD sebesar 1,065.

Koefisien regresi pada variabel jumlah penduduk bernilai 12,035 . Tanda positif pada koefisien regresi menunjukkan hubungan searah antara variabel independen dengan variabel dependennya. Hal ini berarti kenaikan jumlah penduduk sebesar $1 \%$ akan menaikkan nilai tingkat pengungkapan LKPD sebesar 12,035. Koefisien regresi pada variabel pendapatan asli daerah bernilai 8,732. Tanda positif pada koefisien regresi menunjukkan hubungan searah antara variabel independen dengan variabel dependennya. Hal ini berarti kenaikan pendapatan asli daerah sebesar 1\% akan menaikkan nilai tingkat pengungkapan LKPD sebesar 8,732.

Koefisien regresi pada variabel diferensiasi fungsional bernilai $-0,148$. Tanda negatif pada koefisien regresi menunjukkan hubungan berlawanan arah antara variabel independen dengan variabel dependennya. Hal ini berarti kenaikan diferensiasi fungsional sebesar $1 \%$ akan menurunkan nilai tingkat pengungkapan LKPD sebesar 0,148. Koefisien regresi pada variabel belanja modal bernilai -8,697. Tanda negatif pada koefisien regresi menunjukkan hubungan berlawanan arah antara variabel independen dengan variabel dependennya. Hal ini berarti kenaikan belanja modal sebesar 1\% akan menurunkan nilai tingkat pengungkapan LKPD sebesar 8,697 .

\section{KESIMPULAN DAN SARAN Kesimpulan}

Penelitian ini bertujuan untuk melihat seberapa besar pengaruh ukuran pemerintah daerah, tingkat ketergantungan, umur pemerintah daerah, ukuran legislatif, jumlah penduduk, pendapatan asli daerah, diferensiasi fungsional dan belanja modal terhadap tingkat pengungkapan laporan keuangan pemerintah daerah. Berdasarkan pengujian hipotesis yang dilakukan dapat disimpulkan hasil penelitian yaitu ukuran legislatif dan jumlah penduduk berpengaruh terhadap tingkat pengungkapan laporan keuangan pemerintah daerah, sedangkan ukuran pemerintah daerah, tingkat ketergantungan, umur pemerintah daerah, pendapatan asli daerah, diferensiasi fungsional dan belanja modal tidak berpengaruh terhadap tingkat pengungkapan laporan keuangan pemerintah daerah.

\section{Keterbatasan Penelitian}

Penelitian ini memiliki keterbatasan-keterbatasan yang sekaligus dapat menjadi arahan bagi penelitian yang akan datang antara lain: (1) Periode penelitian yang singkat yaitu tahun 2014 sampai tahun 2016 yang memungkinkan akan berdampak pada kurangnya signifikansi data pada hasil penelitian. (2) Penelitian ini hanya mengidentifikasi 2 faktor yang mempengaruhi tingkat pengungkapan Laporan Keuangan Pemerintah Daerah (LKPD). 


\section{Saran}

Berdasarkan beberapa keterbatasan penelitian yang telah diungkapkan, maka peneliti memberikan saran untuk penelitian selanjutnya yaitu: (1) Penelitian selanjutnya bisa menambahkan rentang waktu yang lebih panjang sehingga menghasilkan data yang signifikan dalam penelitian. (2) Penelitian selanjutnya bisa menambahkan faktor-faktor lain terkait dengan tingkat pengungkapan laporan keuangan pemerintah daerah mengingat $56,4 \%$ dari nilai variabel dependen dijelaskan oleh variabel lain diluar penelitian ini.

\section{REFERENSI}

Erlina., Rambe, Omar Sakti., dan Rasdianto. (2015). Akuntansi Keuangan Daerah Berbasis Akrual. Jakarta: Salemba Empat.

Fadilah, Almanita Nurtati Sri dan Nucholisah, Kania. (2016). Pengaruh Karakteristik dan Kompleksitas Pemerintah Daerah terhadap Pengungkapan Laporan Keuangan. Volume 2 No. 1.

Ghozali, Imam. (2009). Aplikasi Analisis Multivariate dengan Program SPSS. Semarang: Badan Penerbit Universitas Diponegoro

Hasanah, Nuramalia., dan Fauzi, Ahcmad. (2017). Akuntansi Pemerintahan. Bogor: Penerbit in Media.

Hendriyani, Ririn dan Tahar, Afrizal. (2015). Analisis Faktor-Faktor yang Mempengaruhi Tingkat Pengungkapan Laporan Keuangan Pemerintah Provinsi di Indonesia. Jurnal Bisnis dan Ekonomi (JBE), Maret 2015 Hal 25-33.

Khasanah, Nur Lailatul dan Rahardjo, Shiddiq Nur. (2014). Pengaruh Karateristik, Kompleksitas, dan Temuan Audit Terhadap Tingkat Pengungkapan Laporan Keuangan Pemerintah Daerah. Diponegoro Journal of Accounting Volume 3 Nomor 3 Tahun 2014 Hal 1 - 11.

Madelia, Mutiara., Rahayu, Sri., dan Yudi. (2017). Pengaruh Karakteristik Pemerintah Daerah, Jumlah Anggota Legislatif dan Opini Audit BPK terhadap Tingkat Pengungkapan Laporan Keuangan Pemerintah Daerah di Provinsi Jambi tahun 2011-2015.

Maulana, Candra dan Handayani, Bestari D. (2015). Pengaruh Karateristik, Kompleksitas Pemerintahan dan Temuan Audit Terhadap Tingakt Pengungkapan Wajib LKPD. Accounting Analysis Journal 4 (4) (2015).

Naopal, Fikrinah., Rahayu, Sri., dan Yudowati, Siska Priyandani. (2017). Pengaruh Karakteristik Daerah, Jumlah Penduduk, Temuan Audit dan Opini Audit terhadap Pengungkapan Laporan Keuangan Pemerintah Daerah. Bandung. Volume 7, Nomor 1, Juni 2017: 56-68. 
Patrick, Patricia A. (2007). The determinants of organizational innovativeness: The adoption of GASB 34 in Pennsylvania local government. Ph.D. dissertation, The Pennsylvania State University, United States - Pennsylvania. (Retrieved August 8, 2011, from Accounting \& Tax Periodicals, Publication No. AAT $3266180)$.

Prasetyo, Agus Budi. (2017). Faktor-Faktor Penentu Tingkat Pengungkapan Laporan Keuangan Pemerintah Daerah Kabupaten/Kota di Jawa Tengah Tahun 20132015. Skripsi. Universitas Stikubank Semarang.

Republik Indonesia. 1945. Undang-Undang Dasar Republik Indonesia Pasal 6 Ayat 2 tentang Pengertian Penduduk.

Republik Indonesia. 2004. Undang-Undang Republik Indonesia Nomor 33 Tahun 2004 tentang Perimbangan Keuangan antara Pusat dan Daerah.

Republik Indonesia. 2005. Peraturan Pemerintah Nomor 24 Tahun 2005 tentang standar akuntansi pemerintahan.

Republik Indonesia. 2006. Peraturan Menteri Dalam Negeri Nomor 13 Tahun 2006 tentang Pedoman Pengelolaan Keuangan Daerah.

Republik Indonesia. 2008. Undang-Undang Republik Indonesia Nomor 14 Tahun 2008 tentang Keterbukaan Informasi Publik.

Republik Indonesia. 2010. Peraturan Pemerintah Republik Indonesia Nomor 71 Tahun 2010 tentang Standar Akuntansi Pemerintahan.

Republik Indonesia. 2011. Peraturan Menteri Dalam Republik Indonesia Nomor 21 Tahun 2011 tentang Pedoman Pengelolaan Keuangan Daerah.

Republik Indonesia. 2013. Peraturan Menteri Dalam Negeri Republik Indonesia Nomor 64 Tahun 2013 tentang Penerapan Standar Akuntansi Pemerintahan Berbasis Akrual Pada Pemerintah Daerah.

Republik Indonesia. 2014. Undang-Undang Republik Indonesia Nomor 23 Tahun 2014 tentang pemerintah daerah.

Republik Indonesia. 2016. Peraturan Pemerintah Republik Indonesia Nomor 18 tahun 2016 tentang perangkat daerah.

Satria, Randa. (2015). Analisis Pengaruh Profitabilitas, Ukuran Dewan Komisaris dan Ukuran Perusahaan Terhadap Pengungkapan Laporan Corporate Social Responsibility (CSR). Skripsi. Politeknik Negeri Padang.

Sekaran, U., dan Bougi, R. (2010). Research Methods for Business a Skill Building Approach 5th Edition. United Kingdom: John Willey \& Sons Ltd Setyaningrum, D dan Syafitri, F. (2012). Analisis Pengaruh Karakteristik 
Pemerintah Daerah terhadap Tingkat Pengungkapan Laporan Keuangan. Jurnal Akuntansi dan Keuangan Indonesia. Vol. 9 No. 2. Jakarta.

Setyowati, L. (2016). Determinan yang Mempengaruhi Pengungkapan Laporan Keuangan Pemerintah Daerah.Jurnal Bisnis dan Manajemen.Volume 6 (1). April 2016.

Suhardjanto, D dan R, Yulianingtyas. (2011). Pengaruh Karakteristik Pemerintah Daerah Terhadap Kepatuhan Pengungkapan Wajib Dalam Laporan Keuangan Pemerintah Daerah (Studi Empiris Pada Kabupaten/Kota di Indonesia). Jurnal Akuntansi \& Auditing, Vol. 8 (1), hlm. 127-142.

Yusup, Junaedi. (2014). Determinan Faktor Yang Mempengaruhi Luas Cakupan Pengungkapan Laporan Keuangan Pemerintah Daerah Kabupaten/Kota di Provinsi Jawa Barat. Jurnal Akuntansi dan Keuangan (JAKA) Vol. 1 No. 1 September 2014 Hal 56-69. 